\title{
A place-based response to Fikile Nxumalo
}

\author{
Siddique Motala \\ University of Cape Town \\ Corresponding Author: siddique.motala@uct.ac.za
}

(Submitted: 26 April 2020; Accepted: 4 September 2020)

\begin{abstract}
This paper is based on the response to Fikile Nxumalo's keynote address at the $10^{\text {th }}$ Annual New Materialism conference in Cape Town. It brings into conversation Nxumalo's practice in early childhood education in North America, with my teaching practice situated in engineering education in Cape Town. Both practices are attuned to place and explore the generative potential of pedagogies that foreground coloniality and anti-black inheritances in context. Resonances between the practices are explored through feminist new materialisms, and I show how a combination of story and place may be utilised to resist dominant discourses from within engineering education.
\end{abstract}

Keywords: cartography, engineering education, geographic information systems, historical mapping, posthumanism

In response to Fikile Nxumalo's thought-provoking keynote at the $10^{\text {th }}$ Annual New Materialisms Conference in Cape Town, South Africa in December 2019, and in keeping with the watery focus of her paper, I wish to 'bring to the surface' some learnings that have emerged for me. This paper is based on my pedagogical practice from when I was situated in an engineering department in a relatively under-resourced university of technology (when compared to the traditional universities situated nearby) in Cape Town. As an engineering educator, I am struck by how engineering education may benefit from an injection of Nxumalo's new materialist-inspired ideas. Additionally, as a geomatics practitioner, I am acutely aware of the importance of place. Geomatics is a relatively new term, and includes the tools and techniques used in the disciplines of land surveying, photogrammetry, geographic information systems (GIS), and cartography. Land, spatial location, and/or place are central to each of these disciplines, so Nxumalo's emphasis on place-based pedagogy ostensibly sits comfortably with geomatics education. But does it, in practice? After considering her keynote address, learnings jump out across several boundaries. As called for by Nxumalo, I will bring to the fore several resonances with my own attempts at place-based practice.

Part of this response was written under a government-enforced national lockdown, to arrest the spread of the COVID-19 virus. It is a time of drastic and unprecedented change, with 
some old power relations being intensified, and others being broken down. As I write this in the confines of my relatively comfortable home, I share the concerns of many: Will my family and friends be safe, healthy, and avoid the virus? Knowing South Africa's violent history and present, will large-scale catastrophic violence be able to be averted? Additionally, will universities (and society at large) be able to co-create a new normal that moves toward care and justice? My middle class existence, unlike those of many financially insecure (mainly black) students, means that I do not have to worry about questions like: How will I be able to survive an extended lockdown with very little money and few material possessions? How can I keep myself safe in this dangerous place? How can I access the online learning material I need with only a shared mobile phone? How can I study in a space in which I have no privacy, and very little internet connectivity? The legacies of colonialism and apartheid are deeply implicated in what Nxumalo calls the 'asymmetrically distributed precarity' (this issue) of students and places. During this time of Coronavirus, the inequalities within societies are becoming increasingly evident, making visible differential vulnerabilities and privileges. The optics of inequality that are usually stark in the average South African university classroom, are even more so online. Poor black students' hardships are revealed by their (under-)preparedness for subjects that rely on computer access. Their online absence is a matter of grave concern. Lecturers are considering how we may offer our classes remotely. Many students have no computers, and their smartphones are their only form of online access. Data is expensive in South Africa, further exacerbating the problem. Furthermore, technologies like GIS that are intimately entangled with technology can exacerbate inequalities or create new forms of exclusion. Privilege is amplified online.

Underlying my pedagogical practice is a posthumanist, vitalist, materialist conception of ethics. It is inspired by Braidotti's nomadic ethics (2006), Barad's agential realism (2007) and Haraway's speculative ethics (2016). For Braidotti, '[e]thics ... is the inquiry about the role, position and relationship that subjects entertain to alterity' (2006: 115). The posthumanist ethical focus on alterity is important because, in its absence, whitewashing could result. Importantly, Nxumalo acknowledges that there are also black critiques of new materialisms and posthumanisms. For example, there are critiques that talk to the whitewashing of the Anthropocene, as well as critiques of how affect theory (which is closely related to posthumanism) could reinscribe universalisms that assume no geographic location. Whilst these are critiques, they are also opportunities to break new ground, and Nxumalo does this with her place-based pedagogy. As she points out, place matters. She, like Haraway (2016), points to the importance of partial and situated points of view. Stories are useful ways to produce such perspectives, and Nxumalo foregrounds stories that centre black children's lives affirmatively.

The first of the critiques above (the whitewashing of the Anthropocene) is related to pervasive whiteness and coloniality that underpin dominant understandings of nature. I would add that this pervasiveness shows itself in South African engineering education too, which is heavily influenced by Western standards. A large amount of the content of South African engineering curricula is dictated by these Western standards, at the expense of local content. This results in the situation where engineers who graduated in South Africa are 'more likely to 
meet the needs of users in the developed world than the needs of local communities' (Winberg, et al., 2014: 2). In my own practice, I too have utilised storytelling toward several modest aims, such as producing socially relevant knowledge that reflects the society that we find ourselves in, as well as to gesture affirmatively towards the future. Additionally, storytelling is used to make students aware of, and subvert, hegemonies simultaneously. Besides stories that I tell, students are also asked to produce personal digital stories using GIS technology and video editing software. This does not represent a fundamental redesign of the geomatics curriculum, but the storytelling intervention does allow for a portion of the curriculum to be dictated by students' own affects, intensities, and place-based knowledge.

The places and spaces that South African students find themselves in are a direct result of race-based and colonial planning. The violence of the original colonial and apartheid racialisation of the land is re-iterated in the violent realities faced by poor people of colour today. This is due in part to the failure of government to undo apartheid town planning. Barad (2007) points out that the past-present-future timeline is not linear or fixed, and that each re-turn of a phenomenon (for example the racialisation of space) is implicated in the conditions of possibility of its other appearances. So Nxumalo's example of white students benefiting from a naturebased education can be seen as an intensification of violence against black bodies.

To illustrate a resonance with Nxumalo's pedagogical practice, one of the stories I tell in class is the story of the Khoi-Dutch contact in the 1650s. I focus on the relationships between the Dutch colonisers and the colonised Khoi (who, with their nomadic lifestyle, their ancient relationships with the natural landscape of the Cape, and their African bodies, exemplified alterity at the time), boundary creation, and cartographic practice to investigate the relationship between colonialism and cartography. This approach is diffractive and genealogical, looking at various phenomena historically, yet simultaneously troubling the linear nature of time. An important aspect of the Dutch-Khoi story is the mapping and partial construction of a boundary hedge by the Dutch. The Dutch settlement led to expected conflict with the Khoi, who used the land of the Cape Peninsula as part of their annual migratory routes. Jan Van Riebeeck, the Dutch commander at the Cape, decided to erect a line of defences, comprising forts, a strong wooden fence, and a line of wild almond trees comprising a boundary hedge. These were intended to demarcate the physical boundary of the Dutch settlement and to keep out the Khoi. This effectively thereafter curtailed the Khoi's nomadic wanderings in the ironically named Cape of Good Hope. 


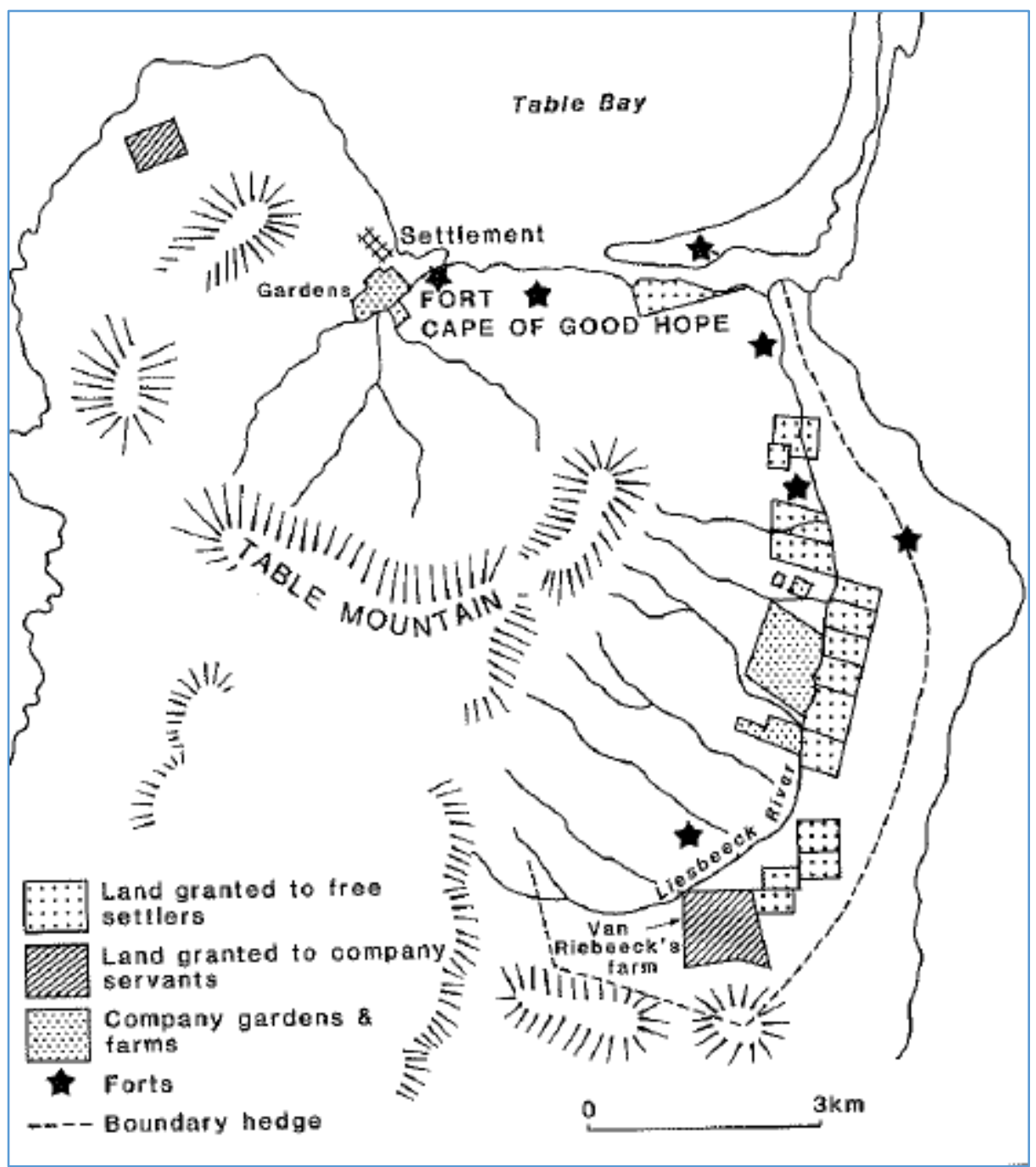

Figure 1 Map of first Dutch farms and boundary hedge at the Cape in the 1650s. (Source: Christopher, 1994: 14)

Figure 1 is a map which ostensibly was intended to communicate spatial information on specific themes, such as Dutch land ownership or the topography of the Cape. While doing this, similar mapping from that time also participated in the creation of sociomaterial reality, which in this case was colonial South Africa. It was also a powerful tool of erasure, giving the impression of an unpopulated (by humans) landscape - terra nullius. On the eastern section of the map, the location of the boundary hedge is shown. In present-day Cape Town, part of the original hedge can be observed physically - a small part of the hedge is still alive in the Kirstenbosch National Botanical Gardens. Figuratively, one can say that the whole hedge is still alive if one zooms out and looks at the map of the demography of Cape Town. GIS students are asked to superimpose the location of Van Riebeeck's hedge onto a demographic map of modern-day Cape Town. 


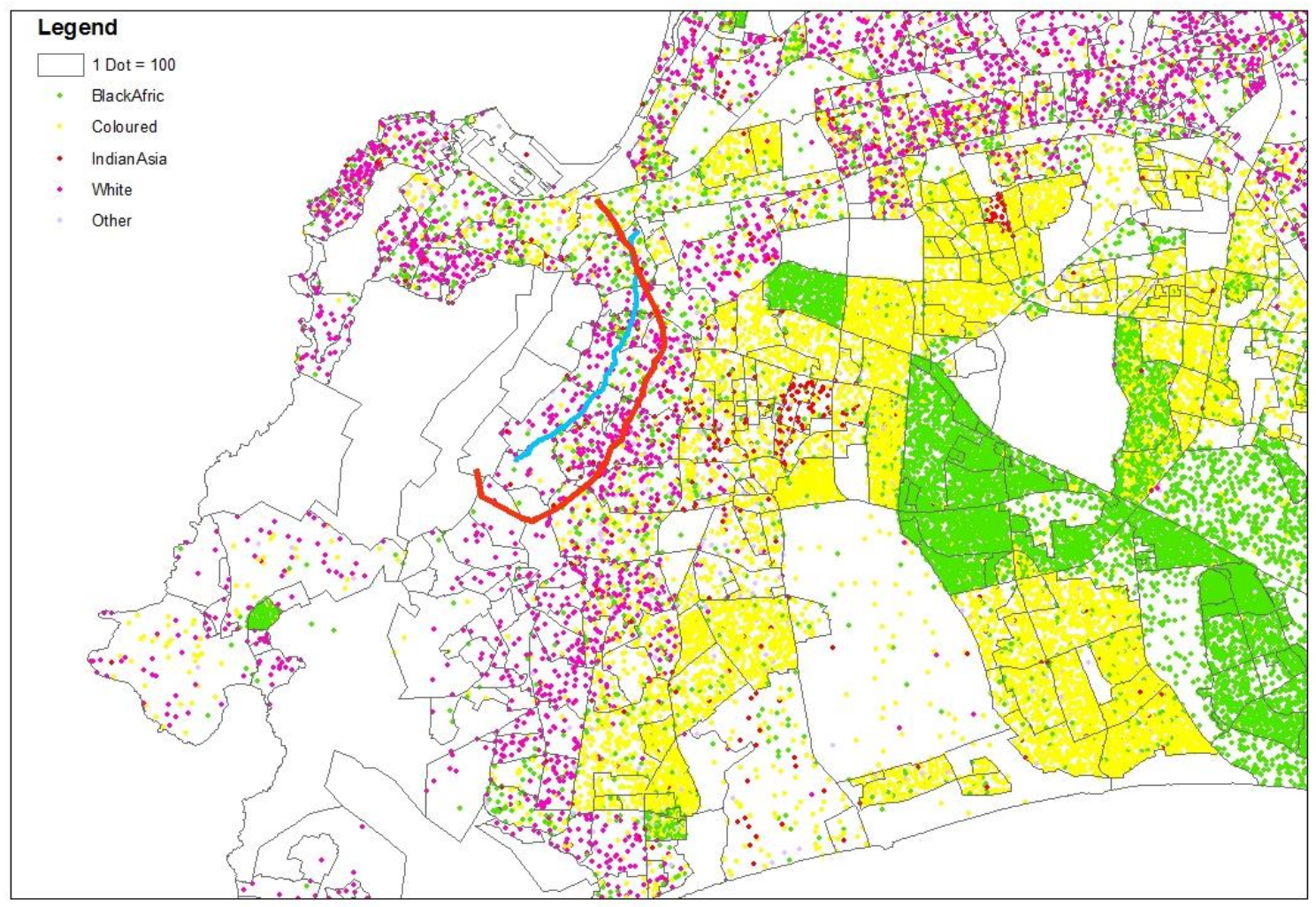

Figure 2 Location of Van Riebeeck's hedge overlaid on a dot density map

Figure 2 is an example of the resulting map. It is a dot density map, showing the populations by race group (these are the race groups that were officially recognised in the apartheid era, and continue to live on in the 'new' South Africa). One green dot $=100$ black people, one purple dot $=100$ white people, one yellow dot $=100$ coloured people and one red dot $=100$ Indian people. The boundary hedge is shown as a red line, and students observe that the location of the original hedge is close to the apartheid boundary between white and coloured areas. They can see that race and place are correlated, and the invisible hedge still largely keeps out black people from the valuable land close to Table Mountain. 


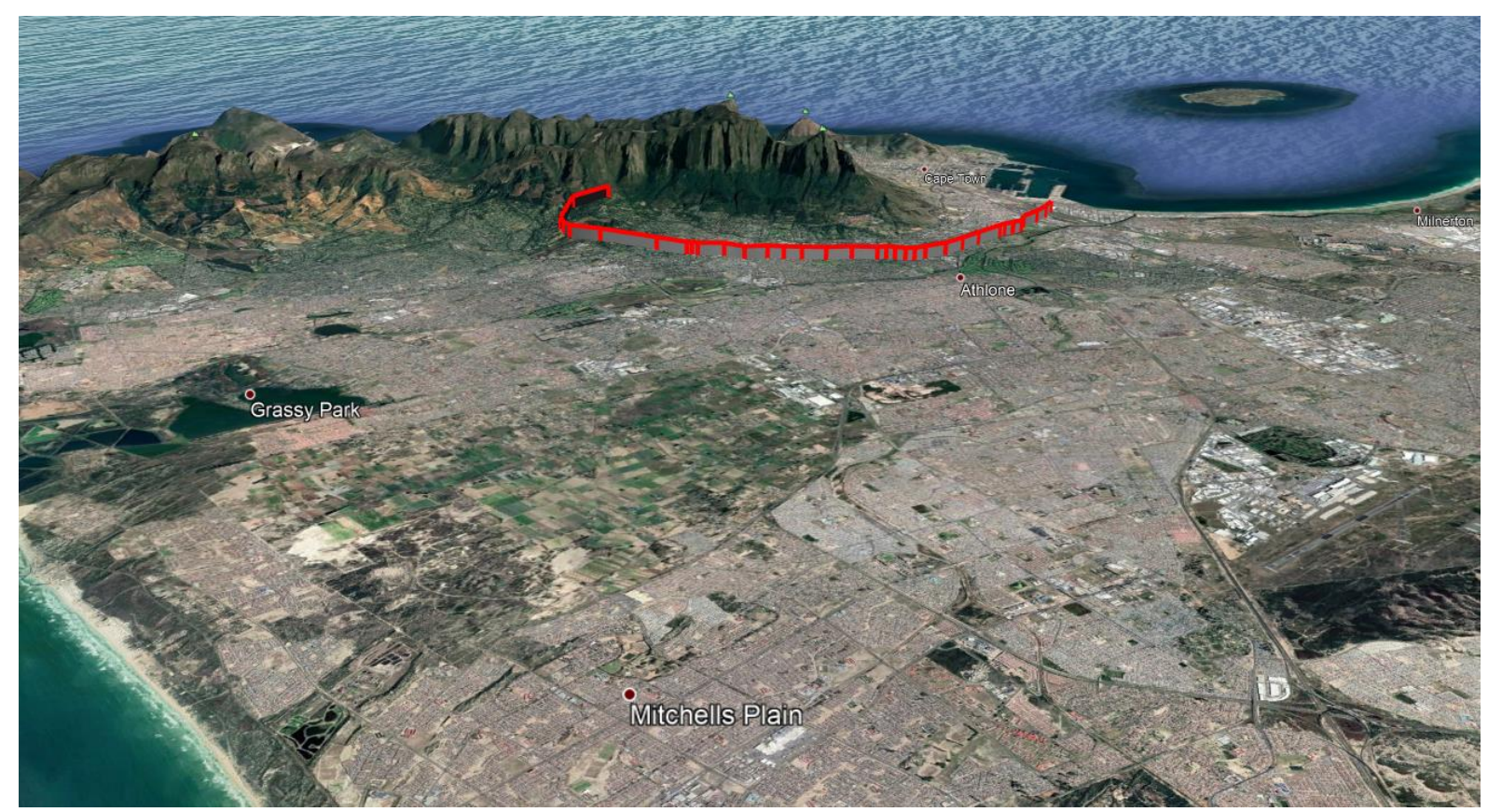

Figure 3 View of Cape Town with boundary hedge

Figure 3 is another representation of the boundary hedge - it was produced by superimposing the location of the boundary hedge over a 3-D visualisation of current-day Cape Town in Google Earth. The hedge is shown as 200-metre-high wall (utilising Trumpian logic), and the vantage point is chosen to be above Mitchells Plain on the Cape Flats. Mitchells Plain, the sprawling township originally built for coloured people during apartheid, is home to some of our students, and undoubtedly home to some of the descendants of the subjugated Khoi that feature in my story. Many (perhaps most) black children who live in townships and urban ghettoes on the Cape Flats have never visited Table Mountain. They see it from their homes; yet, are prevented from accessing it - the boundary hedge still keeps out the native in a hauntological entanglement with the land. These mappings form the backdrop to student explorations of their own lived realities in the city, as well as discussions about the continued violence of colonialism and apartheid. Care is taken to foreground the stories of the marginalised (such as black, female, differently-abled, or foreign students). This re-storying is often affirmative, sometimes painful, sometimes mundane, but always complex. It often reveals, for example, that tropes of poverty and despair are insufficient in capturing the realities of black life in urban South Africa. Like Nxumalo's practice, re-storying brings to the fore relations of resistance to dominant constructs and unsettles deficit or absented depictions of blackness.

Figure 3 presents a different aesthetic to what geomatics students would be accustomed to. A different aesthetic is what Nxumalo's teaching introduces by engaging in an active and embodied experience with children in a waste-filled creek in Austin. Close attention is paid to the specific locations that are encountered in the pedagogical practice, as it is in my teaching. Barad points out that attention to detail is critical, and we must be attentive to 
the material-discursive nature of boundary-drawing practices, the constitutive exclusions that are enacted, and questions of accountability and responsibility for the reconfigurings of which we are part ( 2007: 93).

The places that my students and I encounter are, as Nxumalo points out, active and agentic participants in pedagogical encounters. Another very important place that my students and I encounter is District Six, the location of one of our university's campuses and perhaps the most iconic site of apartheid forced removals. The hauntological significance of pedagogical encounters on the site of District Six has been reported on (Zembylas, et al., 2020). By re-storying District Six and the boundary hedge over the years, we (students and I) are testifying-witnessing with a similar ethic as Nxumalo. Although the anti-blackness of the South African authorities of the past is obvious in these stories, the re-storying makes visible some of the exact mechanisms of oppression that were enacted (such as how apartheid forced removals were planned at a city level and implemented at a personal level). However, I am aware that merely presenting the facts 'will not save us' (Benjamin, 2016: 2) as pointed out by Nxumalo. What is needed is a speculative reimagining, and stories can assist us to imagine alternative subjectivities or realities. Haraway, an advocate for situated storytelling, points out that we 'live with each other in the flesh in ways not exhausted by our ideologies. Stories are much bigger than ideologies. In that is our hope' (2003: 17). She stresses the sympoietic nature of becoming-with as an important navigational tool. Rather than focusing on reconciliation or restoration, she focuses more modestly on getting on together, on partial recuperation. Stories help in this regard, but they can go even further, and fulfil the posthumanist possibility of being both a navigational and analytical tool.

There are several techniques that one may employ to become attuned to silences of alterity. One such technique is related to the identification and countering of incorporation, which is a characteristic of dualism (see Plumwood, 1993). This may be achieved by listening to the story of the underside. Nxumalo points to the importance of being attentive to black children's interests about curiosities toward places and the natural environment. Similarly, but in higher education, I attempt to unsettle deficit depictions of blackness by allowing my students to tell their stories with maps. The storytelling intervention that I have been employing in my teaching (Motala, 2017) is a disruption of the sedimented, positivist and quantitative geomatics curriculum. In analysing the student stories that were produced over the years, several interesting themes emerge. Some stories focus on pain, whilst many transcend the pain by telling their normal, everyday, mundane stories. Gough (2004) suggests that in a posthumanist pedagogy (which he calls a 'cyborg pedagogy'), students should be encouraged to situate the knowledge present in the curriculum in their everyday lives. Similarly, Braidotti (2013) believes that critical posthumanism can assist in the facilitation of responsible education in helping to create communities of learning that look like the society they reflect, serve and help to construct. It was shown that the inclusion of storytelling in GIS education helped students to transcend limited paradigms, take on broader perspectives, encourage empathy, and engage in higher levels of thinking (Motala and Musungu, 2013). Linked to the speculative storytelling that Nxumalo 
advocates, the student stories reveal, for example, future social media influencers, future environmental activists, poets, philanthropists, and a host of other characters in becoming.

After reading Nxumalo's paper, I am left with several questions relating to my practice that are yet to be adequately answered. For example, how can we unsettle anthropocentric priorities and inheritances in engineering education? What do these priorities look like in my context? In engineering education, whilst there is a growing body of work on the incorporation of social and environmental justice in engineering education (see for example Sakellariou, 2013), much needs to be done to trouble anthropocentrism and humanism. Such priorities are ostensibly clear, yet practically complex and contradictory. In the South African engineering landscape, we have sophisticated technologies being deployed next to abject poverty. We have many large engineering works that are started under the premise of empowerment of previously marginalised people; yet, it is these very people who do not see any benefit. In fact, in some cases, like in communities around mines, people and places are left worse off than before. Antiblackness is intensified in these situations. The natural environment suffers, ecosystems are fragmented. The economy grows. Some people prosper. As technology progresses, previously related branches of engineering become increasingly alienated. For example, in the family of professions in which I work, i.e. land surveying, architecture, civil engineering, construction management, and town planning, professionals who in the past worked closely together do not so anymore. In fact, there are some professions that are now antagonistic toward each other as the scope of their work is becoming increasingly interdisciplinary. Nxumalo's plea to consider simultaneously anti-colonial and anti-racist work that focuses on human and the more-thanhuman is especially important in dominant disciplines such as engineering, which are often inward-looking. Her work pays attention to how environmental precarity, anti-blackness, and settler colonialism are interconnected. Of particular importance to responsible engineering education is the cultivation of an environmental ethics through the realisation of the connectedness of everything that inhabits the earth, and the rejection of the anthropocentric view of mankind's superiority over the environment (Haraway, 2016; Shotwell, 2016). In this time of late capitalism, it is a difficult task. A shift in scale is needed to move from the situated knowledge of everyday life to the global. It is pertinent to point out that a posthumanist orientation to pedagogy does not necessarily abandon global knowledge for the sake of the local. There is both a zooming-in and -out, a cutting together/apart (Barad, 2014) - this dual move awakens us to the thinking in movement that is required of critical practitioners.

Teaching toward a decolonial awareness is a difficult task partly because of the proximity of colonisation. In South Africa, the violence of colonisation and apartheid started in the 1650s and officially ended in 1994 - relatively recently. To continue using a water analogy, the stone dropped in a body of water continues to be felt after it has sunk below the surface. There are concentric circles of pain and violence that repeat upon us. Nxumalo's work points to a multipronged approach that is modest yet profound. In using affective water pedagogies, resisting anti-blackness, and disrupting erasures of black relations to place, she is planting seeds of resistance to dominant structures. It manifests as small everyday pedagogical encounters that 
allows Nxumalo's practice to stay with the trouble of contradictory and complex viewpoints. In South Africa, we need that too, and my attempts are micro-instances of activism in an engineering curriculum that is unresponsive to the cries of nature and of subjugated peoples. Against the backdrop of hundreds of years of abuse of black bodies, how can we start reconnecting to each other, to our natural environment (which is also becoming increasingly poisoned) and to troubled knowledge of this place? In getting engineering students to link their technical knowledge to their own lived experience through storytelling, some wonderful disruptions of power relations happen. I see these types of interventions, like Nxumalo's water intervention, as planting seeds of a different type of awareness. This gestures towards a different consciousness that troubles the boundaries that have become so sedimented under the pressures of neoliberalism, anthropocentrism, sexism, racism, and a host of other isms, including colonialism.

\section{Acknowledgements}

This work is based on the research supported in part by the National Research Foundation of South Africa (Grant Number: 105851)

\section{Author Biography}

Siddique Motala is an academic development senior lecturer in the Department of Civil Engineering at the University of Cape Town, South Africa. He is a trained land surveyor and holds a $\mathrm{PhD}$ in education. His research interests and publications include spatio-temporal mapping, storytelling, posthumanism, and innovative pedagogical practices in engineering education. $\mathrm{He}$ was a recipient of the 2017 CHE/HELTASA National Excellence in Teaching Award.

\section{References}

Barad, K. 2007. Meeting the Universe Halfway: Quantum Physics and the Entanglement of Matter and Meaning. Durham: Duke University Press.

Barad, K. 2014. 'Diffracting diffraction: Cutting together-apart, Parallax, 20(3): 168-187.

Benjamin, R. 2016. Racial fictions, biological facts: Expanding the sociological imagination through speculative methods, Catalyst: Feminism, Theory, Technoscience, 2(2): 1-28.

Braidotti, R. 2006. Transpositions: On Nomadic Ethics. Cambridge: Polity Press.

Braidotti, R. 2013. The Posthuman. Cambridge: Polity Press.

Christopher, A. J. 1994. The Atlas of Apartheid. London: Routledge.

Gough, N. 2004. RhizomANTically becoming-cyborg: Performing posthuman pedagogies, Educational Philosophy and Theory, 36(3).

Haraway, D. 2003. The Companion Species Manifesto: Dogs, People, and Significant Otherness. Chicago: Prickly Paradigm Press.

Haraway, D. 2016. Staying with the Trouble: Making Kin in the Chthulucene. Durham: Duke University Press. 
Motala, S. 2017. In/between science and art: Posthumanist ruminations on Geomatics education. Proceedings of the Fourth Biennial Conference of the South African Society for Engineering Education. Cape Town: South African Society for Engineering Education, 194-204.

Motala, S. \& Musungu, K. 2013. Once upon a place: Storytelling in GIS education, 13th SGEM GeoConference on Informatics, Geoinformatics And Remote Sensing. STEF92 Technology, 821-828.

Plumwood, V. 1993. Feminism and the Mastery of Nature. London: Routledge.

Sakellariou, N. 2013. A framework for social justice in renewable energy engineering. In Lucena, J. (ed.) Engineering Education for Social Justice: Critical Explorations and Opportunities. Dordrecht: Springer, 243-267.

Shotwell, A. 2016. Against Purity: Living Ethically in Compromised Times. Minneapolis: University of Minnesota Press.

Winberg, C., Engel-Hills, P., Winberg, S. \& Rip, A. 2014. The ethics of curriculum development: Engineers and technicians in a context of development. Proceedings of 2014 IEEE International Symposium on Ethics in Science, Technology and Engineering. Chicago.

Zembylas, M., Bozalek, V. \& Motala, S. 2020. A pedagogy of hauntology: Decolonizing the curriculum with GIS. Capacious, 1(5). Available at: http://capaciousjournal.com/article/apedagogy-of-hauntology/ (accessed: 17 April 2020). 